\title{
The Relationship Between Pneumonia Severity and The Presence of Anosmia and Ageusia in Hospitalized Patients with Covid-19
}

\section{Covid-19 Hastalarında Pnömoni Şiddeti ile Koku ve Tat Kaybı Varlığı Arasındaki Ilişki}

\author{
Fakih Cihat Eravci ${ }^{1}$, Necdet Poyraz $^{2}$, Celalettin Korkmaz ${ }^{3}$, Hilmi Alper ${ }^{1}$, Miyase Orhan¹, \\ Mehmet Akif Dundar ${ }^{1}$, Pinar Diydem Yilmaz ${ }^{2}$, Hamdi Arbag ${ }^{1}$
}

\begin{abstract}
Öz
Amaç: Literatür, koku ve tat kaybı semptomları yaşayan COVID-19 hasta grubunun daha genç olduğunu, ağırlıklı olarak kadın olduğunu ve bunlarda hastalığın daha hafif seyrettiğini ortaya koydu. Mevcut çalışmada COVID-19 ile hastanede yatan hastalarda koku ve tat kaybı semptomlarının varlığının pnömoni şiddeti ve laboratuvar test sonuçları ile ilişkisinin değerlendirilmesi amaçlandı.

Hastalar ve Yöntem: Ekim 2020-Mart 2021 tarihleri arasında Göğüs Hastalıkları Anabilim Dalı tarafından yatırılan ve toraks bilgisayarlı tomografisi (BT) cekilen hastalar retrospektif olarak değerlendirildi. Hastaların toraks BT bulguları, her bir lob için şiddet skoru ile skorlandı ve toplam skor elde edildi. Pnömoni lezyonların şekline, dağılımına ve görünümüne göre sınıflandırıldı ve laboratuvar test sonuçları kayıt edildi. Bu bulgular koku ve tat kaybı varlığına göre karşılaştırıldı.

Bulgular: Yaş ortalaması 53.0 14.5 yıl (18-89 yıl) olan, 89'u (\%50.2) erkek ve 88'i (\%49.8) kadın olmak üzere toplam 177 hasta değerlendirilmeye dahil edildi. Anosmi ve ageusia semptomlarından en az birini yaşayan (Grup 1) hasta sayısı 67 (\%37.9) olup, geri kalanı (Grup 2) bunlardan hiçbirini yaşamamıştır. Bu semptomları olan, Grup 1 hastalarının yaş ortalaması, Grup 2'ye kıyas ile daha gençti $(p=0,009)$. Toplam pnömoni skoru ve tutulum paternleri açısından gruplar arasında fark saptanmadı ( $p>0.05)$. Bu gruplar laboratuvar sonucları açısından da benzer bulundu $(p>0.05)$

Sonuç: Hastanede yatan hastalarda koku ve tat kaybı prevalansı az değildir ve bu semptomlar gençlerde daha sıktır. Hastanede yatan hastalarda koku ve tat kaybı semptomlarının varlığı ile pnömoni şiddeti ve laboratuvar sonuçları arasında ilişki saptanmadı. Bu semptomların hastanede yatan hastalarda, hastalığın şiddeti açısından prognostik değeri yoktur.
\end{abstract}

${ }^{1}$ Necmettin Erbakan University, Meram Faculty of Medicine, Department of Otorhinolaryngology, Konya, Turkey ${ }^{2}$ Necmettin Erbakan University, Meram Faculty of Medicine, Department of Radiology, Konya, Turkey

${ }^{3}$ Necmettin Erbakan University, Meram Faculty of Medicine, Department of Pulmonology, Konya, Turkey

Anahtar Kelimeler: COVID-19, coronavirüs, nörolojik bulgular, koku kaybı, tat kaybı, pnömoni

\section{Abstract}

Address correspondence to: Fakih Cihat Eravci, Necmettin Erbakan University, Meram Faculty of Medicine, Department of Otorhinolaryngology, Konya, Turkey e-mail: fceravci@gmail.com

Aim: The literature revealed that group of COVID-19 patients who experience anosmia and ageusia symptoms is younger, is predominantly female, and experiences a milder course of the disease. This study aimed to evaluate the relationship of the presence of anosmia and ageusia symptoms with the severity of pneumonia and laboratory test results in hospitalized patients with COVID-19.

Patients and Methods: A retrospective evaluation was made of patients who were hospitalized by the Department of Pulmonology between October 2020-March 2021 and underwent thorax computed tomography (CT). Thorax CT findings of the patients were scored with a severity score for each lobe and a total score was obtained. Pneumonia was classified according to the shape, distribution and appearance

Geliş Tarihi/Received: 22 July 2021 Kabul Tarihi/Accepted: 28 September 2021 of the lesions, and laboratory test results were obtained. These findings were compared according to the presence of anosmia and ageusia symptoms.

Results: Evaluation was made of a total of 177 patients, comprising $89(50.2 \%)$ males and $88(49.8 \%)$ females with a mean age of $53.0 \pm 14.5$ years (range, $18-89$ years). The number of patients who experienced at least one of the symptoms of anosmia and ageusia (Group 1) was $67(37.9 \%$ ) and the rest (Group 2) did not experience any of these symptoms. The Group 1 patients who experienced these symptoms was younger $(p=0.009)$. No difference was determined between groups regarding the total pneumonia score and involvement patterns ( $p>0.05)$. The groups were similar in terms of laboratory results $(p>0.05)$.

Conclusion: The prevalence of anosmia and ageusia in hospitalized patients is not a small number and is more common in the younger population. No association was seen between the presence of these symptoms and milder pneumonia severity and laboratory results. These symptoms do not have prognostic value for the severity of the disease in hospitalized patients.

Key words: COVID-19, coronavirus, neurological manifestations, anosmia, ageusia, pneumonia

Cite this article as: Eravci FC, Poyraz N, Korkmaz C, Alper H, Orhan M, Dundar MA, Yilmaz PD, Arbag H. The Relationship Between Pneumonia Severity and The Presence of Anosmia and Ageusia in Hospitalized Patients with Covid-19. Selcuk Med J 2021;37(4): 339-344
Disclosure: None of the authors has a financial interest in any of the products, devices, or drugs mentioned in this article. The research was not sponsored by an outside organization. All authors have agreed to allow full access to the primary data and to allow the journal to review the data if requested. 


\section{INTRODUCTION}

Coronavirus Disease 2019 (COVID-19) is induced by the novel SARS-CoV-2. The symptomatology of patients with COVID-19 is various (1), with some being asymptomatic and only diagnosed through a positive reverse transcription-polymerase chain test (RT-PCR) without any complaint. However, 5\% of infected patients experience acute respiratory distress syndrome (ARDS), which can result in death (2). Between these two endpoints of symptoms, patients experience a diverse range of mild to moderate symptoms, including loss of the senses of smell and taste, fever, myalgia, fatigue, headache etc. Although the majority of COVID-19-positive patients experience mild to moderate symptoms, $15 \%$ experience pneumonia at different levels of severity $(2,3)$. The degree of the acute systemic inflammatory response to the infection can lead to cardiac, renal and lung involvement and result in a multiple organ failure. The mechanism responsible for disease progression is hyperinflammation, with an increase in cytokines and cytokine storm (3). However, the exact pathophysiological mechanism causing progression has not been clarified as yet.

Olfactory dysfunction and alteration in taste sensation is a commonly accepted symptom of COVID-19, with a reported incidence of $30 \%$ to $80 \%$ $(1,4,5)$. It has been postulated that these symptoms are the result of the neurological tropism of SARSCoV-2. A typical feature of these symptoms is sudden onset and it is thought they might indicate other potential accompanying neurological symptoms. The increasing attention has revealed that neurological symptoms are common in patients with COVID-19 and some reports have shown that altered mental status, hemiparesis, stroke, dementia etc. might predict a higher mortality rate in hospitalized patients $(6,7)$. In contrast, hospitalized patients with anosmia, ageusia and headache have been associated with a more favorable course of the disease (7). In addition, reports that have investigated patients with mild to moderate COVID-19 have revealed a higher incidence of anosmia and ageusia compared with hospitalized patients (8). Furthermore, a study has stated that COVID-19 patients with anosmia have significantly lower serum IL-6 levels associated with a milder disease course (4). Another study has shown that rather than the initial presence of olfactory and gustatory symptoms having a prognostic value, the persistence of these symptoms is associated with a more severe course (9). Therefore, the controversy about this topic is ongoing. The aim of this study was to evaluate the relationship of the presence of anosmia and ageusia symptoms with the severity of pneumonia and laboratory test results in hospitalized patients with COVID-19 in order to determine the clinical and radiological prognosis.

\section{PATIENTS AND METHODS}

This study was approved by the Ministry of Health, Republic of Turkey (Number: 2021-04-20T12_45_40) and the Local Ethics Committee (Number:2021/3230) and was conducted in accordance with the principles of the Declaration of Helsinki. A retrospective assessment was made of the thorax CT scans of consecutive patients hospitalized with COVID-19 in the Department of Pulmonology between October 2020 and March 2021. The patients with COVID-19 was confirmed with a positive reverse transcriptionpolymerase chain test (RT-PCR). The study inclusion criteria were defined as patient age $>18$ years and availability of chest CT images. Patients with a history of lung disease or who had undergone any intervention to the lungs were excluded from the study. A total of 177 patients CT images which was the severest during the hospitalization were included in the study. The patients were separated into two groups; Group 1 included hospitalized patients with COVID-19 who experienced at least one of anosmia and ageusia symptoms and Group 2 comprised patients who did not experience these symptoms. The demographic data, the presence of anosmia and ageusia symptoms, and laboratory test results (Highest value for D-Dimer, Ferritin, C-reactive protein and Neutrophil; Lowest value for Fibrinogen, Lymphocyte and Platelet during hospitalization) were extracted from the digital medical records system.

\subsection{Measurements}

CT imaging was performed using a Somatom Drive (Siemens Healthineers, Erlangen, Germany) scanner and the images were evaluated by two thoracic radiologists (N.P. and P.D.Y.) on a Syngo Via Workstation (Siemens Healthineers). Unenhanced CT scans were obtained from top to the base of the lung for all patients. The scanning parameters were: tube voltage, $120 \mathrm{kV}$; tube current-time product, 50-100 mAs; pitch, 0.6; matrix, $512 \times 512$; slice thickness, 3 $\mathrm{mm}$, and reconstructed slice thickness, $1.5 \mathrm{~mm}$. The images were examined in lung (width: 1000 - 1500 $\mathrm{HU}$, level:700 to $-550 \mathrm{HU}$ ) and mediastinal window settings (width: 300-350 HU, level: 30 - $40 \mathrm{HU}$ ). The images were reviewed separately by the 2 radiologists 
and conclusions were reached by consensus. The typical images for COVID-19 pneumonia as shown in Figure 1 and described in the Radiological Society of North America Expert Consensus were accepted as COVID-19 pneumonia and the images not showing COVID-19 pneumonia were defined as normal (10).

The diffusiveness of the involvement was classified as none $(0 \%)$, minimal (1\%-25\%), mild (26\%-50\%), moderate $(51 \%-75 \%)$, or severe $(76 \%-100 \%)$ for each lobe of the lung. These classifications were scored from 0 to 4 for each lobe and the overall lung pneumonia severity total score (PSTS) was obtained as the total of the five lobe scores (range of possible PSTS; 0 to 20) (11). Lesions of the lung were classified according to the distribution (peripheral, central, or peripheral and central), shape (patchy, round, or patchy and round) and appearance (ground-glass opacity [GGO], consolidation, or GGO and consolidation). GGO was defined as lesions with hazy increased lung attenuation with preservation of bronchial and vascular margins. Consolidation was defined as lesions with opacification with obscuration of margins of vessels and airway walls.

\subsection{Statistical Analysis}

The data obtained in the study were analyzed with SPSS version 22 software (SPSS, Chicago, IL, USA). In the descriptive analysis of the data, continuous variables were presented as mean \pm standard deviation values and categorical variables as frequencies and percentages. The normality distribution analysis of the data was evaluated using the Kolmogorov-Smirnov test and according to the results, parametric tests were used. The Student's t-test was used for the comparisons of numerical data of age, laboratory tests, length of stay and pneumonia severity total score. The remaining categorical data of gender, the presence of pneumonia, and distribution, shape and appearance of lesions were compared with the Pearson chi-square test. A value of $p<0.05$ was considered statistically significant.

\section{RESULTS}

The total 177 patients comprised 89 (50.3\%) males and $88(49.7 \%)$ females with a mean age of $53.0 \pm 14.4$ years (range, $18-89$ years). The patients who experienced at least one of anosmia and ageusia symptoms group (Group 1) of 67 patients (38\%) comprised $33(49 \%)$ males and 34 (51\%) females with a mean age of $49.4 \pm 14.7$ years. The patients who did not experience any of anosmia and ageusia symptoms (Group 2) of 110 (62\%) patients comprised
$56(51 \%)$ males and $54(49 \%)$ females with a mean age of $55.2 \pm 13.9$ years. Although the groups were similar in terms of gender $(p=0.283$ and $p=0.588$, respectively), Group 1 was younger $(p=0.009)$. The groups were similar in terms of length of stay in hospital, as 10.4 \pm 8.1 days in Group 1 and 10.0 17.4 days in Group 2.

In Group 1, 8 of $67(12 \%)$ patients did not have lung involvement and in Group 2, 12 of 110 (11\%) patients did not have pneumonia on the thorax CT examinations. The mean pneumonia severity total score was $5.7 \pm 3.6$ (range, 0 - 14) in Group 1, and $5.3 \pm 3.6$ (range, 0 - 15) in Group 2. The number of lesions, distribution, shape and appearance, in both groups are shown in Table 1. No statistically significant difference was determined between the groups in respect of lung involvement, pneumonia severity total score, distribution, shape and appearance of lesions $(p=0.812, p=0.548, p=0.502, p=0.633$ and $p=0.921$, respectively). The laboratory test results are presented in Table 2, showing statistical similarity between the groups.

\section{DISCUSSION}

The results of the present study demonstrated that

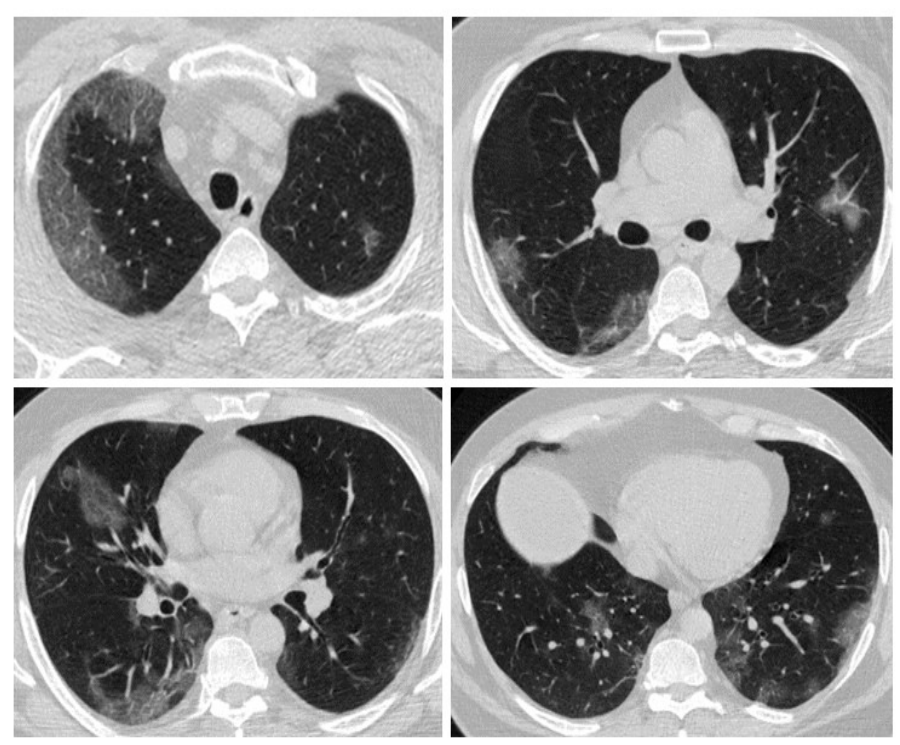

Figure 1. Axial thin-section unenhanced CT from a 53-year-old male with COVID-19 showing bilateral peripheral ground glass opacities with varying degrees of patchy and rounded morphology in all lobes. 
Table 1. The number of lesions, distribution, shape and appearance, in both the groups

\begin{tabular}{llll}
\hline & Group 1 (n:67) & Group 2 (n:110) & P value \\
\hline Pneumonia Severity Total Score & $5.73 \pm 3.61$ & $5.39 \pm 3.67$ & $0.54^{*}$ \\
Distribution of lesion & $8(12 \%)$ & $11(10 \%)$ & \\
$\quad$ None & $52(77 \%)$ & $92(83 \%)$ \\
$\quad$ Peripheral & $0(0 \%)$ & $1(1 \%)$ \\
Central & $7(11 \%)$ & $6(6 \%)$ \\
$\quad$ Peripheral and Central & $8(12 \%)$ & $11(10 \%)$ \\
Shape of lesion & $37(55 \%)$ & $55(50 \%)$ \\
$\quad$ None & $1(2 \%)$ & $5(4 \%)$ \\
Patchy & $21(31 \%)$ & $39(36 \%)$ \\
Round & $8(12 \%)$ & $11(10 \%)$ \\
Patchy and Round & $51(76 \%)$ & $85(78 \%)$ \\
Appearance of lesion & $3(4 \%)$ & $7(6 \%)$ \\
$\quad$ None & $5(8 \%)$ & $7(6 \%)$ \\
$\quad$ GGO & & \\
Consolidation &
\end{tabular}

* Student T test; GGO: ground-glass opacity

the prevalence of anosmia and ageusia in hospitalized patients is not a small number and the chest CT findings of hospitalized patients with COVID-19 were similar for both those who experienced or did not experience anosmia and ageusia symptom during the disease. Moreover, no significant differences were determined between the groups in respect of the laboratory test results and length of hospital stay. The spectrum of the symptoms of COVID-19 is broad, ranging from asymptomatic to ARDS. The most common presentation of hospitalized cases are pulmonary symptoms. Parameters that determine the progression of the disease have not yet been clarified. The mechanism thought to be responsible is uncontrolled immune mediated response $(3,12)$. This leads to a cytokine storm syndrome, correlated with the disease severity, which affects cardiac, renal and respiratory systems and may result in multiple organ failure.

COVID-19 has neurological manifestations, the most common of which are taste and smell disturbances, and these may be the only symptoms during the course of the disease $(13,14)$. The exact pathophysiologic mechanism has not yet been clarified but the two thought to be responsible are the neurotrophic features of the virus and the cytopathic effect of the inflammatory response (15). In COVID19-related anosmia, an increase of inflammatory markers in the olfactory epithelium suggests a direct intensive inflammation in nasal mucosa. This shows how the patients encounter a nasal cytokine storm after the entrance of COVID-19 from ACE-2 receptors, in spite of having no sinonasal symptoms (16). It has also been shown that the expression levels of ACE2 receptors have an inverse relationship with type 2 immune response biomarkers (17). Nevertheless,

Table 2. The laboratory test results of the groups

\begin{tabular}{llll}
\hline & Group 1 & Group 2 & P value \\
\hline D-dimer $(\mu \mathrm{g} / \mathrm{mL})$ & $481 \pm 796$ & $1106 \pm 4689$ & $0.174^{*}$ \\
Ferritin $(\mathrm{ng} / \mathrm{mL})$ & $507 \pm 583$ & $517 \pm 675$ & $0.916^{*}$ \\
Fibrinogen $(\mathrm{mg} / \mathrm{dL})$ & $492 \pm 183$ & $511 \pm 181$ & $0.503^{*}$ \\
CRP $(\mathrm{mg} / \mathrm{dL})$ & $56 \pm 57$ & $76 \pm 89$ & $0.071^{*}$ \\
Leukocyte (Count) $\left(10^{-3} / \mu \mathrm{L}\right)$ & $7.9 \pm 3.9$ & $8.7 \pm 4.4$ & $0.177^{*}$ \\
Neutrophil (Count) $\left(10^{-3} / \mu \mathrm{L}\right)$ & $6.5 \pm 7.3$ & $7.9 \pm 11.3$ & $0.321^{*}$ \\
Lymphocite (Count) $\left(10^{-3} / \mu \mathrm{L}\right)$ & $1.3 \pm 0.6$ & $1.2 \pm 0.6$ & $0.297^{*}$ \\
Thrombocyte (Count) $\left(10^{-3} / \mu \mathrm{L}\right)$ & $256 \pm 127$ & $264 \pm 100$ & $0.677^{*}$ \\
\hline
\end{tabular}

* Student T test 
previous reports have stated that patients with anosmia experience a milder disease and it has been alleged that patients have a more severe nasal cytokine storm in the nasal cavity and this hinders the systemic uncontrolled immune response $(4,8)$. This theory has been supported with the findings that anosmia rates were lower in hospitalized patients, although others studies have not found the relationship of milder disease in hospitalized patients with anosmia $(9,12$, 18). Studies of patients with mild to moderate disease have shown incidence of anosmia at $70 \%-80 \%$, but it has also been shown that patients misinterpret the loss of smell and taste resulting in a lower rate of anosmia cases (18). In order to overcome this problem, the current study population included the symptoms of both anosmia and ageusia in the analyses and 38 $\%$ of all the study population patients self-reported these symptoms during the course of the disease. In addition, previous studies have revealed that COVID19-related anosmia is seen at a younger age and with female predominance $(18,19)$. In the current study results, it was also seen that the group of patients with anosmia and ageusia was younger compared with those that did have these symptoms. However, the gender analysis showed no difference, with similar rates in both genders regarding these symptoms.

Studies investigating the neurological effects of COVID-19 have shown that severe neurological involvement such as altered mental status, hemiparesis, stroke, dementia etc. predict a higher mortality rate in hospitalized patients $(6,7,13)$. In contrast, hospitalized patients with anosmia, ageusia and headache have been associated with more a favorable course of the disease (7). In addition, lymphopenia and increased CRP have been associated with higher mortality rates (20). The attribution of prognostic value to anosmia and ageusia was not supported with the current study results. The pneumonia severity total score and laboratory test results were used for outcome measures of disease severity in the study and these were similar in both patients with and without anosmia and ageusia symptoms. This demonstrates that the theory which alleges that patients with anosmia experience milder disease because of the higher immune response may not be valid for all patients and there may be some other as yet unknown mechanisms in the pathogenesis. Some other studies have suggested that rather than these symptoms in the early stages of the disease having prognostic value, the persistence of these symptoms for up to 20 days is associated with a severe disease course (9). Since the current study had the limitations of retrospective design, the duration of the symptoms was not known. This also shows the importance for future studies of recording symptoms prospectively with the information of the starting time and the duration. Furthermore, as only the hospitalized patients were included in this study in order to make a homogenous group, the current study population may not reflect the whole picture. Therefore, to elucidate the relationship of the severity of COVID-19 and these symptoms, the inclusion of both outpatients and inpatients might provide more reliable and satisfactory results. Nevertherless, the results of this study show that the presence of anosmia and ageusia did not differ in patients with severe disease.

There are previous studies that searched the relation of the COVID-19 severity in anosmia patients. However, to best of our knowledge, this present study is the first that have investigated this relationship in hospitalized COVID-19 patients. Our study has several limitations regarding the retrospective nature. The duration of the symptoms of anosmia and ageusia, oxygen saturations of the patients during the hospitalization could not extracted from the medical records. Additionally, the presence of anosmia and ageusia symptoms have been recorded with subjective patient information rather than obtaining with objective olfactory and taste tests since the risk of contamination.

\section{CONCLUSION}

In conclusion, the results of this study demonstrated the prevalence of anosmia and ageusia in hospitalized patients and it was seen to be not a small number. The results also showed that these symptoms are more common in the younger population. Furthermore, the study results showed that the presence of anosmia and ageusia symptoms in hospitalized patients are not associated with a milder pneumonia severity and laboratory results. These symptoms do not have prognostic value about the severity of the disease in hospitalized patients.

Conflict of interest: Authors declare that there is no conflict of interest between the authors of the article.

Financial conflict of interest: Authors declare that they did not receive any financial support in this study.

Address correspondence to: Fakih Cihat Eravci, Necmettin Erbakan University, Meram Faculty of Medicine, 
Department of Otorhinolaryngology, Konya, Turkey

Phone: +905055196459

e-mail: fceravci@gmail.com

\section{REFERENCES}

1. Altin F, Cingi C, Uzun $T$, et al. Olfactory and gustatory abnormalities in COVID-19 cases. Eur Arch Otorhinolaryngol 2020;277:2775-81.

2. Wu Z, McGoogan JM. Characteristics of and important lessons from the coronavirus disease 2019 (COVID-19) outbreak in China: Summary of a report of 72314 cases from the Chinese center for disease control and prevention. Jama 2020;323:1239-42.

3. Cekerevac I, Turnic TN, Draginic N, et al. Predicting severity and intrahospital mortality in COVID-19: The place and role of oxidative stress. Oxid Med Cell Longev 2021;2021.

4. Sanli DET, Altundag A, Kandemirli SG, et al. Relationship between disease severity and serum IL-6 levels in COVID-19 anosmia. Am J Otolaryngol 2021;42:102796.

5. Rajkumar I, Anand K, Revathishree K, et al. Contemporary analysis of olfactory dysfunction in mild to moderate Covid 19 patients in a tertiary health care centre. Indian J Otolaryngol Head Neck Surg 2020:1-5.

6. Eskandar EN, Altschul DJ, de la Garza Ramos R, et al. Neurologic syndromes predict higher in-hospital mortality in COVID-19. Neurology 2021;96:e1527-38.

7. Ghaffari M, Ansari H, Beladimoghadam N, et al. Neurological features and outcome in COVID-19: Dementia can predict severe disease. J Neurovirol 2021;27:86-93.

8. Yan $\mathrm{CH}$, Faraji F, Prajapati DP, et al. Self-reported olfactory loss associates with outpatient clinical course in Covid-19. Int Forum Allergy Rhinol 2020;10:821-31.

9. Vaira LA, Hopkins C, Petrocelli M, et al. Do olfactory and gustatory psychophysical scores have prognostic value in COVID-19 patients? A prospective study of 106 patients. J Otolaryngol Head Neck Surg 2020;49:56.

10. Simpson S, Kay FU, Abbara S, et al. Radiological society of north America expert consensus document on reporting chest CT findings related to COVID-19: Endorsed by The Society of Thoracic Radiology, The American College of Radiology, and RSNA. Radiol Cardiothorac Imaging 2020;2:e200152.
11. Chung $M$, Bernheim $A$, Mei $X$, et al. CT imaging features of 2019 novel coronavirus (2019-nCoV). Radiology 2020;295:202-7.

12. Moein ST, Hashemian SM, Mansourafshar B, et al. Smell dysfunction: A biomarker for COVID-19. Int Forum Allergy Rhinol 2020;10:944-50.

13. Mao L, Jin $H$, Wang $M$, et al. Neurologic manifestations of hospitalized patients with coronavirus disease 2019 in Wuhan, China. JAMA Neurol 2020;77:683-90.

14. Korkmaz MÖ, Eğilmez OK, ÖzçelikMA, etal. Otolaryngological manifestations of hospitalised patients with confirmed COVID-19 infection. Eur Arch Otorhinolaryngol 2020:1-11.

15. Salahuddin H, Afreen E, Sheikh IS, et al. Neurological predictors of clinical outcomes in hospitalized patients with COVID-19. Front Neurol 2020;11.

16. Kandemirli SG, Altundag A, Yildirim D, et al. Olfactory bulb MRI and paranasal sinus CT findings in persistent COVID-19 anosmia. Acad Radiol 2021;28:28-35.

17. Jackson DJ, Busse WW, Bacharier LB, et al. Association of respiratory allergy, asthma, and expression of the SARSCoV-2 receptor ACE2. J Allergy Clin Immunol 2020;146:2036.e203.

18. Sehanobish E, Barbi M, Fong V, et al. COVID-19-Induced anosmia and ageusia are associated with younger age and lower blood eosinophil counts. Am J Rhinol Allergy 2021:19458924211004800.

19. Hopkins C, Surda $P$, Whitehead E, et al. Early recovery following new onset anosmia during the COVID-19 pandemican observational cohort study. J Otolaryngol Head Neck Surg 2020;49:1-6.

20. Huang $\mathrm{C}$, Wang $\mathrm{Y}$, Li X, et al. Clinical features of patients infected with 2019 novel coronavirus in Wuhan, China. Lancet 2020;395:497-506. 